\title{
MODEL PEMBELAJARAN BERBASIS WEB UNTUK MENINGKATKAN HASIL BELAJAR SISWA
}

\author{
Nursamsilis Lutfin ${ }^{1, A}$ Vivit Agreani ${ }^{2}$ Susalti Nur Arsyad ${ }^{3}$ \\ ${ }^{1,2,3}$ Fakultas Keguruan Dan Ilmu Pendidikan \\ Universitas Bosowa Makassar
}

\begin{abstract}
ABSTRAK
Penelitian ini secara umum bertujuan (1) Untuk mengetahui penerapan model pembelajaran berbasis web untuk meningkatkan hasil belajar siswa kelas VIII SMPN 8 Kota Makassar (2) Untuk mengetahui minat siswa dalam penerapan model pembelajaran berbasis web untuk meningkatkan hasil belajar siswa kelas VIII SMPN 8 Kota Makassar. Penelitian ini termasuk jenis eksperimental research dengan meteode quasi eksperimental. Penelitian ini dilakukan di SMPN 8 Makassar dengan popolasi 810 siswa. Peneliti menggunakan teknik pengambilan sampling secara random. Total sampel yang digunakan adala 30 siswa. Peneliti membagi sampel menjadi dua kelas yaitu kelas eksperimen dan kelas kontrol. Intrument penelitian yang digunakan adalah test, angket dan wawancara. Berdasarkan analisis data dapat disimpulkan bahwa Model Pembelajaran Berbasis Web sangat menarik untuk diterapkan dalam proses pembelajaran. Model Pembelajaran Berbasis Web dapat membantu mahasiswa mengembangkan kemampuan Bahasa Indonesia siswa. Model Pembelajaran Berbasis Web Menggunakan sangat efektif untuk diterapkan untuk menghindari kejenuhan dan kebosanan mahasiswa dalam mengikuti proses pembelajaran.
\end{abstract}

Kata Kunci: Model Pembelajaran, Web, Hasil Belajar

\section{PENDAHULUAN}

Masalah bahasa dalam dunia pendidikan merupakan peranan yang sangat penting. Pengajaran Bahasa Indonesia haruslah berisi usaha-usaha yang dapat membawa serangkaian keterampilan. Keterampilan tersebut erat hubungannya dengan proses-proses yang mendasari pikiran. Semakin terampil seseorang berbahasa semakin cerah dan jelas pula jalan pikirannya. Menurut Tarigan, dalam Muchlisoh (1996: 257) ada empat aspek keterampilan berbahasa yang mencakup dalam pengajaran bahasa adalah: (1) keterampilan menyimak 
(listening skills); (2) keterampilan berbicara (speaking skills); (3) keterampilan membaca (reading skills); dan (4) keterampilan menulis (writting skills), dan keempat keterampilan tersebut saling berhubungan satu sama Lain.

Kegiatan belajar mengajar dipengaruhi oleh beberapa faktor, salah satunya adalah metode pembelajaran. Menurut T. Raka Joni dalam Soli Abimanyu (2008: 2-5) metode adalah cara kerja yang bersifat relatif umum yang sesuai untuk mencapai tujuan tertentu. Metode merupakan cara pelaksanaan kegiatan dalam mencapai tujuan yaitu tujuan pembelajaran. Salah satu metode pembelajaran yang telah terbukti mampu mengoptimalkan hasil belajar adalah penggunaan episodic memory. Menurut Edward (2009: 64) peta pikiran (mind mapping) adalah cara paling efektif.

Media yang akan digunakan dalam proses pembelajaran memerlukan perencanaan yang baik. Heinich, dan kawan-kawan dalam Arsyad (2005) mengajukan model perencanaan penggunaan media yang efektif dikenal dengan istilah ASSURE (Analyze learner characteristics (menganalisis karakteristik umum kelompok sasaran), State objective (menyatakan atau merumuskan tujuan pembelajaran), Select or modify media (memilih, memodifikasi, atau merancang dan mengembangkan materi dan media yang tepat), Utilize (menggunakan materi dan media), Require learner response (meminta tanggapan dari siswa) and Evaluate (mengevaluasi proses belajar).

Kriteria pemilihan media bersumber dari konsep bahwa media merupakan bagian dari sistem instruksional secara keseluruhan. Ada beberapa faktor yang perlu dipertimbangkan dalam pemilihan media yaitu:

1. Keterbatasan sumber setempat. Media yang bersangkutan tidak terdapat pada sumber-sumber yang ada, maka harus dibeli atau dibuat sendiri.

2. Apakah untuk membeli atau memproduksi sendiri ada dana, tenaga dan fasilitasnya.

3. Faktor yang menyangkut keluwesan, kepraktisan dan ketahanan media yang bersangkutan untuk waktu yang lama. Bisa digunakan dimanapun dengan peralatan yang ada disekitarnya dan kapan pun serta mudah dijinjing dan dipindahkan.

4. Efektifitas dalam jangka waktu yang panjang.

Berdasarkan apa yang telah dijelaskan diatas, maka penelitian ini mengambil judul "Model Pembelajaran Berbasis Web Untuk Meningkatkan Hasil Belajar Siswa.".

\section{TINJAUAN PUSTAKA}

\section{Pengertian Multimedia}

Menurut Andi Pramono (2003: 17) lahirnya teknologi multimedia merupakan hasil kemajuan teknologi elektronik, komputer dan perangkat lunak, kemampuan penyimpanan dan pengolahan gambar digital dalam belasan juta warna serta reproduksi suara maupun video dalam bentuk digital telah memungkinkan multimedia terjangkau oleh masayarakat umum pemakai komputer pribadi. 
Menurut Drs. St. Mulyanta, S.Kom.,M.Kom. (2009: 1) multimedia adalah kombinasi dari komputer dan video sehingga secara prinsip multimedia merupakan gabungan dari tiga elemen dasar yaitu suara, gambar dan teks.

\section{Objek Multimedia}

Menurut Ariesto Hadi Sutopo (2003: 8), komponen multimedia adalah gambaran yang dapat dilihat dari tipe data dasar yang disimpan dalam objek multimedia. Setiap objek multimedia memerlukan cara penanganan tersendiri, dalam hal kompresi data, penyimpanan, dan pengambilan kembali untuk digunakan. Multimedia terdiri dari beberapa objek yaitu :

1. Teks, merupakan dasar pengolahan kata dan informasi berbasis multimedia.

2. Image, secara umum image atau grafik berarti gambar atau photo. Semua objek yang disajikan dalam bentuk grafik adalah bentuk setelah dilakukan Pengumpulan Materi. Pembuatan encoding dan tidak mempunyai hubungan langsung dengan waktu.

3. Animasi, berarti gerakan image atau video, seperti gerakan orang yang sedang melakukan kegiatan dan lain-lain.

4. Audio, penyajian audio merupakan cara lain untuk lebih memperjelas pengertian suatu informasi. Suara dapat lebih memperjelas karakteristik suatu gambar.

5. Full motion dan live video, full motion berhubungan dengan penyimpanan sebagai video clip sedangkan live video merupakan hasil pemrosesan yang diperoleh dari kamera.

6. Interactive link, sebagian multimedia adalah interaktif, dimana pengguna dapat menekan mouse atau objek pada screen seperti button atau teks dan menyebabkan program melakukan perintah tertentu.

\section{Evaluasi Media}

Secara khusus evaluasi atau penilaian juga diartikan sebagai proses pemberian nilai berdasarkan data kuantitatif hasil pengukuran untuk keperluan pengambilan keputusan. Evaluasi adalah sebuah proses dimana keberhasilan yang dicapai. dibandingkan dengan seperangkat keberhasilan yang diharapkan. Perbandingan ini kemudian dilanjutkan dengan pengidentifikasian faktor-faktor yang berpengaruh pada kegagalan dan keberhasilan. Evaluasi ini dapat dilakukan secara internal oleh mereka yang melakukan proses yang sedang dievaluasi ataupun oleh pihak lain, dan dapat dilakukan secara teratur maupun pada saat-saat yang tidak beraturan. Proses evaluasi dilakukan setelah sebuah kegiatan selesai, dimana kegunaannya adalah untuk menilai/menganalisa apakah keluaran, hasil ataupun dampak dari kegiatan yang dilakukan sudah sesuai dengan yang diinginkan.

Dari pengertian-pengertian tentang evaluasi yang telah di kemukakan beberapa ahli di atas, dapat diambil kesimpulan tentang evaluasi yakni, evaluasi merupakan suatu kegiatan yang dilakukan seseorang untuk mengukur dan 
memberi nilai secara obyektif dan valid, dimana seberapa besar manfaat pelayanan yang telah dicapai berdasarkan tujuan dari obyek yang seharusnya diberikan dan yang nyata apakah hasil-hasil dalam pelaksanaan telah efektif dan efisien.

\section{Model Pembelajaran Berbasis Web (E-Learning)}

Pembelajaran berbasis web yang populer dengan sebuta Web-Based Education (WBE) atau kadang disebut e-learning (electronic learning) dapat didefinisikan sebagai aplikasi teknologi web dalam dunia pembelajaran untuk sebuah proses pendidikan . secara sederhana dapat dikatakan bahwa semua pembelajaran dilakukan dengan memanfaatkan teknologi internet dan selama proses belajar dirasakan terjadi oleh yang mengikutinya, maka kegiatan it dapat disebut sebagai pembelajaran berbasis web.

Model pembelajaran dirancang dengan mengintegerasikan pembelajaran berbasis web dalam progam pembelajaran konvensional tatap muka. Proses pembelajaran konvensional tatap muka dilakuakan dengan pendekatan student centered learning (SCL) melauli kerja kelompok model ini menuntut partisipasi peserta didik yang tinggi.

Sekalipun teknologi web memungkinkan pembelajaran dialkukan virtual secar penuh, namun kesempatan itu tidak dipilih. Interaksi satu sama lain untuk dapat berkomunikasi langsung secara tatap muka masih dibutuhkan.

Menurut Jaya Kumar C. Koran (2002), e-learning adalah pembelajaran yang menggunakan rangkaian elektronik (LAN, WAN, atau internet) untuk menyampaikan isi pembelajaran, interaksi atau bimbingan. Rosenberg (2001) menekankan bahwa e-learning merujuk pada penggunaan teknologi internet untuk mengirimkan seraingkain solusi yang dapat meningkatkan pengetahuan dan ketrampilan. Hal ini senada dengan Campbell (2002), Kamarga (2002) yang intinya menekankan penggunaan internet dalam pendidikan sebagai hakikat $e$ learning.

Perbedaan pembelajaran tradisional dengan e-learning, yaitu kelas tradisional. Guru dianggap sebagai orang yang serba tahu dan ditugaskan untuk menyalurkan ilmu pengetahuan kepada pelajarnya. Sedangkan di dalam pembelajaran e-learning fokus utamanya adalah pelajar. Pelajar mandri pada waktu tertentu dan bertanggung jawab untuk pembelajaranya. Suasana pembelajaran e-learning akan memaksa pelajar memainkan peranan yang lebih aktif dalam pembelajaranya. Pelajar membuat perancangan dan mencari materi dengan usaha dan inisiatif sendiri.

Pendapat haughey (Rusman, 2007) tentang pengembangan e-learning adalah ada tiga kemungkinan dalam pengembangan sistem pembelajaran berbasis internet, yaitu web course, web centric course, dan web enhanced course. Web course adalah penggunaan untuk keperluan pendidikan, yang mana mahasiswa dan dosen sepenuhnya terpisah dan tidak diperlukan adanya tatap muka. Seluruh bahan ajar, diskusi, konsultasi, penugasan, latihan, ujian, dan kegiatan pembelajaran lainya sepenuhnya disampaikan melalui internet. Web centric 
course adalah penggunaan internet yang memadukan antara belajar jarak jauh dan tatap muka. Sebagaian materi disampaikan melalui internet, dan sebagaian lagi melalui tatap muka, fungsinya saling melengkapi. Web enhanced course adalah pemanfaatan internet untuk menunjang peningkatan kualitas pembelajaran yang dilakukan di kelas. Fungsi internet adalah untuk memberikan pengayaan dan komunikasi antara mahasiswa dengan dosen, sesama mahasiswa, anggota kelompok, atau mahasiswa dengan narasumber lain.

\section{METODE PENELITIAN}

Dalam penelitian ini, peneliti menggunakan jenis penelitian quasi eksperimental design. Peneliti menggunakan jenis penelitian tersebut disebabkan jumlah populasi yang terlalu banyak yaitu 9 kelas sehingga sulit bagi meneliti untuk mengambil sampel secara acak. Dalam penelitian ini, peneliti membagi kelas menjadi dua kelompok yaitu kelompok eksperimen yang akan mengguanakan model pembelajaran berbasis web dalam proses pembelajarannya dan kelas control yang menggunakan metode pengajaran konvensional dalam proses pembelajarannya. Penelitian ini akan dilaksanakan di SMP Negeri 8 Makassar. Dalam penelitian ini populasi yang akan digunakan adalah seluruh siswa kelas VIII di SMPN 8 Makassar yang berjumlah kurang lebih 270 siswa yang terdiri dari 9 kelas. Teknik pengambilan sampel yang digunakan adalah teknik Random Sampling. Cara atau teknik ini dapat dilakukan jika analisis penelitiannya cenderung deskriptif dan bersifat umum. Peneliti menggunakan teknik ini karena populasi dan sampel dalam penelitian ini bersifat homogen, yaitu seluruh siswa kelas VIII SMPN 830 Makassar. Dari hasil pengambilan sampel secara acak maka didapatlah kelas VIII A sebagai kelas kontrol. Dan untuk kelas uji coba didapat kelas VIII D. Instrumen atau alat yang digunakan untuk mengumpulkan data penelitian ini adalah instrument tes untuk mengukur hasil belajar dan angket angket untuk mengetahui ketertarikan siswa pada model pembelajaran yang digunakan dan wawancara untuk mendukung data angket siswa.

\section{HASIL PENELITIAN}

\section{Interpretasi dari Hasil Tes Siswa.}

Bagian Ini memaparkan data hasil pretest dan posttest siswa sebelum dan sesudah diberikan treatment menggunakan Model Pembelajaran Berbasis Web.

a. Hasil Tes siswa pada pretest unutk kelompok eksperimen dan kelompok kontrol.

Seperti yang dijelaskan sebelumnya bahwa setelah tabulasi dan menganalisis nilai iswa ke dalam bentuk persentase, mereka diklasifikasikan menjadi enam tingkatan berdasarkan Puskur (2006: 35). Tabel berikut adalah skor pretest siswa dan persentase kelompok eksperimen dan kontrol. 
Tabel 1 Persentase Nilai Pretest

\begin{tabular}{llllll}
\hline \multirow{2}{*}{ Klasifikasi } & \multirow{2}{*}{ Skor } & \multicolumn{2}{c}{ Kelompok eksperimen } & \multicolumn{2}{c}{ Kelompok kontrol } \\
\cline { 3 - 6 } & & Frekuensi & Persentase & Frekuensi & Persentase \\
\hline Sangat baik & $81-100$ & 0 & 0 & 1 & 5.0 \\
Baik & $61-80$ & 2 & 10.0 & 1 & 5.0 \\
Cukup & $41-60$ & 5 & 25.0 & 11 & 55.0 \\
Kurang & $21-40$ & 13 & 65.0 & 7 & 35.0 \\
Sangat Kurang & $1-20$ & 0 & 0 & 0 & 0 \\
\hline Total & & 20 & $100 \%$ & 20 & $100 \%$ \\
\hline
\end{tabular}

Berdasarkan data pada Tabel 1, pada kelompok experimen dari 20 siswa, ada $2(10 \%)$ siswa yang masuk kategori baik, 5 (25\%) siswa masuk ketegori cukup baik, $13(65 \%)$ siswa masuk pada kategori kurang, dan tidak ada siswa yang masuk kategori sangat baik dan sangat kurang. Sedangkan pada kelompok control, ada $1(5 \%)$ siswa yang masuk kategori sangat bagus, $1(5 \%)$ siswa masuk pada kategori baik, 11 (55\%) siswa masuk kategori cukup, 7 (35\%) siswa masuk pada kategori kurang dan tidak ada siswa yang masuk pada kategori sangat kurang.

b. Nilai rata-rata dan standar deviasi dari pretest siswa untuk kelompok eksperimen dan kelompok kontrol.

Sebelum treatment dilakukan, baik kelompok eksperimen dan kontrol diberi pretest untuk mengetahui pengetahuan awal siswa. Selanjutnya, tujuan dari pengujian ini adalah untuk mengetahui apakah kelompok eksperimen dan kelompok kontrol pada tingkat yang sama atau tidak.

Setelah menghitung hasil pretest siswa, nilai rata-rata dan standar deviasi disajikan pada tabel berikut.

Tabel 2 Nilai Rata-rata dan Standard Deviasi dari Pretest Siswa

\begin{tabular}{lll}
\hline Kelompok & Skor Rata-rata & Standar Deviasi \\
\hline Eksperimental & 36.340 & 11.480 \\
Kontrol & 46.355 & 13.992 \\
\hline
\end{tabular}

Berdasarkan klasifikasi hasil tes kosakata, nilai rata-rata dari kelompok kontrol (46.355) dianggap masih rendah dengan standar deviasi 13.992. Sedangkan pada kelompok eksperimen, nilai rata-rata yang diperoleh adalah 36.340 dengan standar deviasi 11.480 dan masih masuk pada kategori rendah.

c. Hasil Posttest siswa untuk Kelompok eksperimen dan kelompok kontrol.

Pada bagian ini jilai siswa diklasifikasikan ke dalam lima tingkat. Skor tersebut kemudian ditabulasikan dan dianalisis menjadi persentase. Tabel berikut adalah ringkasan statistik posttest siswa dari kedua kelompok. 
Tabel 3 Persentase Nilai Posttest Siswa

\begin{tabular}{llllll}
\hline \multirow{2}{*}{ Klasifikasi } & \multirow{2}{*}{ Skor } & \multicolumn{2}{c}{ Kelompok eksperimen } & \multicolumn{2}{c}{ Kelompok kontrol } \\
\cline { 2 - 6 } & & Frekuensi & Persentase & Frekuensi & Persentase \\
\hline Sangat bagus & $81-100$ & 7 & 35.0 & 0 & 0 \\
Baik & $61-80$ & 9 & 45.0 & 12 & 60.0 \\
Cukup & $41-60$ & 4 & 20.0 & 8 & 40.0 \\
Kurang & $21-40$ & 0 & 0 & 0 & 0 \\
Sangat Kurang & $1-20$ & 0 & 0 & 0 & 0 \\
\hline Total & & 20 & $100 \%$ & 20 & $100 \%$ \\
\hline
\end{tabular}

Dari klasifikasi, nilai, dan persentase tingkat kelompok eksperimen diilustrasikan dalam tabel di atas bahwa dari 20 siswa, tidak ada siswa yang berada pada kategori cukup, kurang dan sangat kurang. Ada 7 (35\%) siswa pada kategori sangat bagus dan ada $9(45 \%)$ siswa pada kategori baik akan tetapi masih ada $4(20 \%)$ siswa yang masuk kategori cukup. Sedangakan pada kelompok kontrol tidak ada siswa yang berada pada kategori sangat baik, kurang dan sangat kurang. Ada $12(60 \%)$ siswa pada kategori baik dan ada $8(40 \%)$ siswa berada pada kategori cukup baik.

Berdasarkan uraian di atas, jelas bahwa ada peningkatan signifikan peningkatan kemampuan kosa kata siswa pada kelompok eksperimen selama penelitian.

d. Nilai rata-rata dan standar deviasi posttest siswa pada Kelompok eksperimen dan

kelompok kontrol.

Pada Tabel berikut, peneliti menyajikan skor rata-rata dan standar deviasi kedua kelompok.

Tabel 4 Nilai Rata-rata dan Standar Deviasi Posttest siswa

\begin{tabular}{lll}
\hline Kelompok & Skor Rata-rata & Standar Deviasi \\
\hline Eksperimental & 72.450 & 13.650 \\
Kontrol & 62.460 & 9.328 \\
\hline
\end{tabular}

Pada tabel di atas dapat dilihat bahwa kelompok kontrol memiliki nilai ratarata 74.67 dengan standar deviasi yang diperoleh 7.535. Sedangkan untuk kelompok eksperimen, nilai rata-rata yang diperoleh adalah 80.33 dengan standar deviasi senilai 9.463 .

e. Uji signifikansi (t-test).

T-test adalah tes untuk mengukur apakah ada atau tidak perbedaan yang signifikan antara hasil nilai rata-rata siswa dalam pretest dan posttest dihasilkan oleh kelompok kontrol dan kelompok eksperimen. Dengan menggunakan analisis inferensial dari t-test atau uji signifikansi dijalankan oleh SPSS Versi 20, perbedaan signifikan dapat lebih mudah untuk menganalisis. Tingkat signifikansi adalah $(\alpha)=0,05$ dan derajat kebebasan $(\mathrm{df})=38, \mathrm{~N} 1+\mathrm{N} 2-2$, jumlah siswa dari 
kedua kelompok (masing-masing 20). Tabel berikut menggambarkan hasil nilai ttest:

Tabel 5 Hasil t-test Untuk Kelompok Eksperimen dan Kontrol

\begin{tabular}{lccl}
\hline Variabel & \multicolumn{1}{c}{$\begin{array}{l}\text { Nilai } \\
\text { probabilitas }\end{array}$} & $\boldsymbol{\alpha}$ & Keterangan \\
\hline $\begin{array}{l}\text { Pretest kelompok kontrol dan } \\
\text { eksperimental }\end{array}$ & 0.19 & 0.05 & Tidak signifikan \\
$\begin{array}{l}\text { Posttest kelompok kontrol dan } \\
\text { eksperimental }\end{array}$ & 0.00 & 0.05 & signifikan \\
\hline
\end{tabular}

Berdasarkan hasil analisis data seperti dirangkum pada tabel 5 pretest kontrol dan kelompok eksperimen, peneliti menemukan bahwa p-Nilai (Nilai Probabilitas nilai) lebih tinggi dari $\alpha(0,19>0$. 05) dan derajat kebebasan 38 . Berdasarkan Nilai-test t dari kelompok eksperimen dan kontrol dalam pretest itu dapat disimpulkan bahwa ditidak ada perbedaan yang signifikan. Sementara itu, pNilai dari posttest dari kedua kelompok diperoleh hasil lebih rendah dari $\alpha(0,00$ $<0,05)$ dan derajat kebebasan adalah 38. Nilai t-test dari kedua kelompok pada posttest dapat disimpulkan ada perbedaan yang signifikan. Hal ini menunjukkan bahwa hipotesis alternatif $\left(\mathrm{H}_{1)}\right.$ diterima dan, tentu saja, hipotesis nol $\left(\mathrm{H}_{0)}\right.$ ditolak. Hal ini menunjukkan bahwa penggunaan Model Pembelajaran Berbasis Web secara signifikan meningkatkan hasil belajar siswa dalam kelompok eksperimen.

\section{Interpretasi dari Hasil Analisis Data Kuesioner.}

Tujuan dari penyebaran kuesioner adalah untuk mengetahui minat siswa selama penelitian. Kuesioner tersebut dibagikan kepada siswa dalam kelompok eksperimen setelah treatment dilakuakan. Semua pertanyaan dijawab secara terpisah berdasarkan pendapat mereka setelah treatment. Hasilnya Kuesioner menunjukkan siswa tertarik untuk belajar bahasa Indonesia dengan menggunakan Model Pembelajaran Berbasis Web. Hal ini ditunjukkan dengan persentase kuesioner siswa yang ditunjukkan pada tabel berikut ini:

Tabel 6 Persentase Hasil Angket Siswa

\begin{tabular}{lllll}
\hline No. & Klasifikasi & Jarak & Frekuensi & Persentase \\
\hline 1. & Sangat Berminat & $85-100$ & 6 & $30 \%$ \\
2. & Berminat & $69-84$ & 12 & $60 \%$ \\
3. & Cukup & $51-68$ & 1 & $5 \%$ \\
4. & Kurang Berminat & $36-50$ & 1 & $5 \%$ \\
5. & Sangat Tidak Berminat & $20-35$ & 0 & 00.00 \\
\hline Total & & 20 & Total \\
\hline
\end{tabular}

Berdasarkan klasifikasi di atas, menunjukkan bahwa ada sekitar 6 (30\%) siswa mengatakan sangat berminat, $12(60 \%)$ siswa mengatakan berminat dan ada $1(5 \%)$ siswa mengatakan cukup berminat dan ada $1(5 \%)$ siswa yang 
mengatakan kurang berminat serta tidak ada yang memilih sangat tidak berminat. Dari data, ditemukan bahwa semua siswa memiliki minat yang tinggi dalam belajar bahasa Indonesia dengan Model Pembelajaran Berbasis Web.

\section{PEMBAHASAN}

Hasil posttest menunjukkan bahwa penggunaan Metode memberikan progress significantly terhadap hasil belajar siswa. Ini berarti semua siswa bisa menigkatkan kemampuan Bahasa Indonesia mereka; hal ini terbukti dengan nilai rata-rata siswa sebelum dan sesudah perlakuan mendapat kenaikan seperti yang dinyatakan sebelumnya. Pencapaian hasil belajar Bahasa Indonesia menunjukkan nilai kelompok eksperimen dibandingkan dengan kelompok control lebih baik.

Data statistik berdasarkan pada t-tes melalui SPSS Versi 20 untuk menguji hipotesis menunjukkan bahwa nilai probabilitas dari kelompok eksperimen lebih rendah dari alpha $(\alpha)$ di mana $(0,00<0,05)$. Ini berarti bahwa $\mathrm{H}_{1}$ dari hipotesis diterima.

Kuesioner diberikan kepada siswa untuk mengetahui minat siswa terhadap pelaksanaan metode. Berdasarkan hasil kuesioner yang diberikan kepada kelompok eksperimen, hasil yang diperoleh siswa tergolong sangat tinggi. Dari fakta ini, ditunjukkan bahwa cara guru bahasa Indonesia dalam memberikan materi berhubungan erat dengan minat atau respons siswa terhadap guru bahasa Indonesia. Manajemen kelas guru menyatukan pengalaman, kemampuan dan perasaan serta minat untuk mengajar bahasa Indonesia.

Hasil kuesioner yang diberikan setelah posttest menunjukkan bahwa siswa memiliki ketertarikan pada metode ini. Kuesioner diberikan setelah posttest untuk kelompok eksperimen untuk mengetahui minat siswa dalam menggunakan metode tersebut. Berdasarkan analisis kuesionerer penelitian menyimpulkan bahwa siswa tertarik untuk belajar melalui metode tersebut.

\section{KESIMPULAN}

Berdasarkan analisis data dapat disimpulkan bahwa Model Pembelajaran Berbasis Web sangat menarik untuk diterapkan dalam proses pembelajaran. Model Pembelajaran Berbasis Web dapat membantu mahasiswa mengembangkan kemampuan Bahasa Indonesia. Model Pembelajaran Berbasis Web sangat efektif untuk diterapkan untuk menghindari kejenuhan dan kebosanan mahasiswa dalam mengikuti proses pembelajaran.

\section{DAFTAR PUSTAKA}

Arikunto, Suharsimi. 1998. Prosedur Penelitian Suatu Pendekatan Praktek. Jakarta: Bina Aksara.

Fansury, A.H., Agreani, A.V. and Lutfin, N., 2018. Web-Based Learning Model Using Hot Potatoes Applications to Increase Language Student achievement. PEOPLE: International Journal of Social Sciences, 4(2). 
Hadjar, Ibnu. 1999. Dasar-Dasar Metodologi Penelitian Kuantitatif dalam Pendidikan. Jakarta: PT Kurnia Alam Perista Raja Grafindo Persada

Brown, H. Douglas \& Lee, Heekyeong. (2015). Teaching by Principle: An Interactive Approach to Language Pedagogy. New York: Pearson Education, Inc.

Gay, L. R., et al. (2011). Educational Research: Competencies for Analysis and Applications. New York: Macmillan Publishing Company.

Marie, J.B. \& Wahyudi, E.S. (2006) Emergent Theory and Technology in Elearning. Breukelen, Netherlands. P.6.

Mulhuda. M. Ali. 2013, April. Enhancing Students' Comprehension in Grammar by using Hotpotatoes. Journal of Education. Blitar: Cakrawala Pendidikan Published. STKIP PGRI Blitar. Vol 15 (1), pp. $22-26$

Mulhuda. M. Ali, 2010, Improving Students' Listening Skill through Web Based Teaching Strategy. Islamic University of Malang.

Solanki, D, Shyamlee. (2012) Use of Technology in English Language Teaching and Learning: An Analysis. International Conference on Language, Medias and Culture, IPEDR vol. 33,Singapore, IACSIT press. P. 151.

Warschauer, M., \& D. Healey. (1998). Computers and language learning: An overview. Language Teaching, 31, 57-71.

Youwen Yang. (2010) Journal of Language Teaching and Research, Vol. 1, No. 6, pp. 909-912, Computer-assisted Foreign Language Teaching: Theory and Practice 